\title{
Food and nutritional care quality indicators in hospital
}

\author{
Rosa Wanda Diez-Garcia ${ }^{1}$, Camila Cremonezi J apur ${ }^{1}$, Maria Angélica Tavares de Medeiros ${ }^{2}$ \\ 1. Laboratory of Food Practices and Behavior - PrátiCA, Nutrition and Metabolism, Department of Internal Medicine, \\ Faculty of Medicine of Ribeirão Preto, University of São Paulo, SP, Brazil. 2. Department of Health Science, Federal \\ University of São Paulo - Baixada Santista, Brazil
}

Correspondence: Rosa Wanda Diez-Garcia. Address: Faculty of Medicine of Ribeirão Preto, University of São Paulo, Department of Internal Medicine, Nutrition and Metabolism, Laboratory of Food Practices and Behavior - PrátiCA. Av. dos Bandeirantes, 3900. Monte Alegre, Ribeirão Preto, SP, Brazil. Cep 14049-900. E-mail: wanda@fmrp.usp.br

Received: February 28, 2013

Accepted: April 2, 2013

Online Published: April 11, 2013

DOI : $10.5430 /$ jha.v2n3p132

URL: http://dx.doi.org/10.5430/jha.v2n3p132

\section{Abstract}

Hospital malnutrition and increased prevalence of hospitalized patients with chronic diseases require hospital improvements in nutritional care quality. This study describes the construction of indicators to assess the quality of hospital food and nutritional care. We obtained a data bank containing information about 37 hospitals as well as their Hospital Food and Nutrition Service (HFNS) applying a questionnaire to the HFNS coordinators of each institution. We collected data about the activities of the clinical dietitians and administrative dietitian, meal production and management, and characteristics of the hospital diet. We grouped the obtained data into two corpora of actions, designated Nutritional Care Quality (NCQ) and Food Service Quality (FSQ). Each corpora comprised four indicators. The NCQ indicators included inpatient dietary coverage actions, evaluation and monitoring of nutritional status actions, actions on integration of nutritional assistance activities within the team, and actions supporting diet therapy. The FSQ indicators comprised mediation actions with users and other hospital sectors, autonomy and management control actions, meal production and qualification actions, and staff qualification actions. Systematizing the NCQ and FSQ indicators is important to support the Food and Nutritional Care Quality in Hospitals (FNCQH).

\section{Key words}

Nutritional care, Hospital food, Hospital nutrition, Nutrition care indicators, Food service quality

\section{I ntroduction}

Hospital malnutrition ${ }^{[1,2]}$ and the increasing prevalence of hospitalized patients with chronic diseases ${ }^{[3-6]}$ require hospital improvements in food and nutritional care quality. Malnourished inpatients have an impact on hospitalization costs and length of stay ${ }^{[3,7-9]}$ so an effective short-, medium-, and long-term nutritional intervention in patients with chronic diseases is paramount.

Nutritional care quality depends on actions that target the patient - evaluation and monitoring of their nutritional status, assessment of their food intake, strategies and mechanisms that ensure they comply with the nutritional care therapy, and involvement of an integrated multi professional team. However, nutritional care quality also relies on hospital food quality, which includes infrastructure, good Hospital Food and Nutrition Service (HFNS) staff, and varied and flexible diet. All these factors should guarantee that the patients' demands are met and that they participate in the treatment ${ }^{[10-14]}$. 
Hospitals should adapt nutritional care to changes within the institution, targeting efficient actions and improved care quality ${ }^{[15]}$. Many aspects of the Food and Nutritional Care Quality in Hospitals (FNCQH) have been investigated such as hospital diet quality control ${ }^{[10,12,16]}$, adoption of screening criteria to detect malnutrition upon hospital admission ${ }^{[17-19]}$, and diagnosis of nutritional disorders upon admission ${ }^{[7,20]}$. However, few studies have dealt with a set of actions for the FNCQH.

Although the nutritional deficiencies of hospitalized patients have long been a matter of concern in Brazil ${ }^{[1]}$, hospitals have different expectations about inpatient clinical nutrition practice. This area is often undervalued and considered simply as a support service ${ }^{[10,21]}$. However, continuous improvement in the quality of inpatient nutritional care may convert the specific necessities of the patient into effective clinical results, thereby reducing hospitalization costs ${ }^{[8,22]}$.

In order to assess food and nutritional care descriptively, it is essential to know about the variables that influence its quality, establish indicators that will allow for standardization of a periodic evaluation, and implement actions that will contribute to improved efficacy of this type of assistance. The indicators can be used to compare clinical nutrition practices in institutions of different characteristics and to point out the weaknesses of the HFNS of the various hospitals. Therefore, the aim of this work is to describe the construction of indicators for assessment of the Food and Nutritional Care Quality in Hospitals, using the data collected from 37 hospitals ${ }^{[23,24]}$.

\section{Methods}

Criteria employed in the construction of hospital food and nutritional care quality indicators.

First, we build a data bank containing information about various aspects of the institutions under study (Table 1) on the basis of a questionnaire named Instrument for Evaluation of Food and Nutritional Care ${ }^{[23]}$ and applied it to the HFNS coordinators of each hospital. We investigated 37 hospitals; 27 hospitals were located in municipalities of the state of São Paulo, more specifically Campinas (17 hospitals) and Ribeirão Preto (10 hospitals), whereas ten hospitals were located in the city of Florianópolis, capital of the State of Santa Catarina. One-third of the hospitals (12 hospitals) were public (7 university hospitals and 5 government institutions). However, the majority of beds were public (79\% of beds from Florianópolis; 67\% from Ribeirão Preto and 51\% from Campinas). In terms of type, 81.1\% were general hospitals; 27.0\% were large-sized (more than 150 beds) and 54.1\% were medium-sized (between 51 and 150 beds). Both Campinas and Ribeirão Preto are important scientific-technological health centers with various services of nationwide recognition. The cities included in the present work are home to various public (federal and state) and private universities.

The data dealt with the characteristics of the institution, the structure of the HFNS, the position of the HFNS in the hospital organizational structure, the staff profile, and the characteristics of the current clinical nutrition practices and of the food service management (Figure 1). This information was used to qualify the institutions and to indicate which variables influence the quality of hospital nutritional care ${ }^{[24]}$.

Following this analysis, we organized the criteria into two corpora of actions; designated Nutritional Care Quality (NCQ) and Food Service Quality (FSQ). Each corpus comprised four indicators (Table 2). These indicators, consisting of between 3 and 6 criteria, were measured as percentage of existence of that group of actions in a certain institution. Each indicator thus corresponded to $25 \%$ of the total NCQ and FSQ value. FNCQH was determined as the mean percentage that each institution complied with the NCQ and FSQ indicators. Since the actions are interconnected and interdependent, the distribution of points considered the same value to each group of the action. Systematization of the NCQ and FSQ indicators is important because it helps evaluate direct and indirect hospital actions regarding patient care. 
Table 1. Aspects evaluated in the first stage of data analysis

Evaluated Aspects

Identification and characteristics of the institutions

Structure of the HFNS

Position of the HFNS in the hospital organizational structure

Available human resources

Staff profile

Evaluation and monitoring of the patients’ nutritional status

Inter-staff relationship

Evaluation of user satisfaction

Nutritional support team

Meal production activities

Quality control of meal production

Staff training

HFNS Planning

Hospital diet

\section{Types of Information}

Type of hospital, number of beds, occupation, juridical nature, administrative sphere, classification in the Brazilian Unified Health System (SUS).

Type of management, number of employees at the HFNS, number of (clinical and administrative) dietitians, number of meals produced, types of statistic control, outpatient clinics, HFNS infrastructure (computers and physical area), meal schedule.

Organizational chart.

Number of dietitians per area of activity, duty shift system per area of activity, contract work, number of beds per dietitians, per HFNS employees.

Graduation year, titles, continuous professional development, professional experience, institutional support to continuous education.

Nutritional evaluation by means of biochemical and anthropometric measurements, patient's history, monitoring of the nutritional evaluation, information entry in the medical records, specific printed forms, monitoring of patients' food intake, visits to patients, guidance at discharge, diet prescription, and protocols.

Relation between nursing and medical staff, interconsultations, clinical visits, integration activities with other services and the hospital.

Criteria and instruments for evaluation of user satisfaction, employees responsible for conducting the evaluation, main issues concerning the patients, diet modification by the patient.

Presence of a nutritional support team, participants and their functions.

Budget autonomy, cost control, purchase system.

Menu, standard recipes, specialized kitchens, tasting, good practice manual.

Instruments for staff evaluation and training.

Goal setting, records, participation of the institution, representation in administrative organs, objectives and priorities of the HFNS, issues most frequently requested by the institution, issues within the multi professional team, users and hospital administration.

Diet manual, nutritional information, types of diets, statistical control of the diets, production and use of nutritional supplements, quality of the utensils used for serving the diet in the wards.

HFNS: Hospital Food and Nutrition Service 


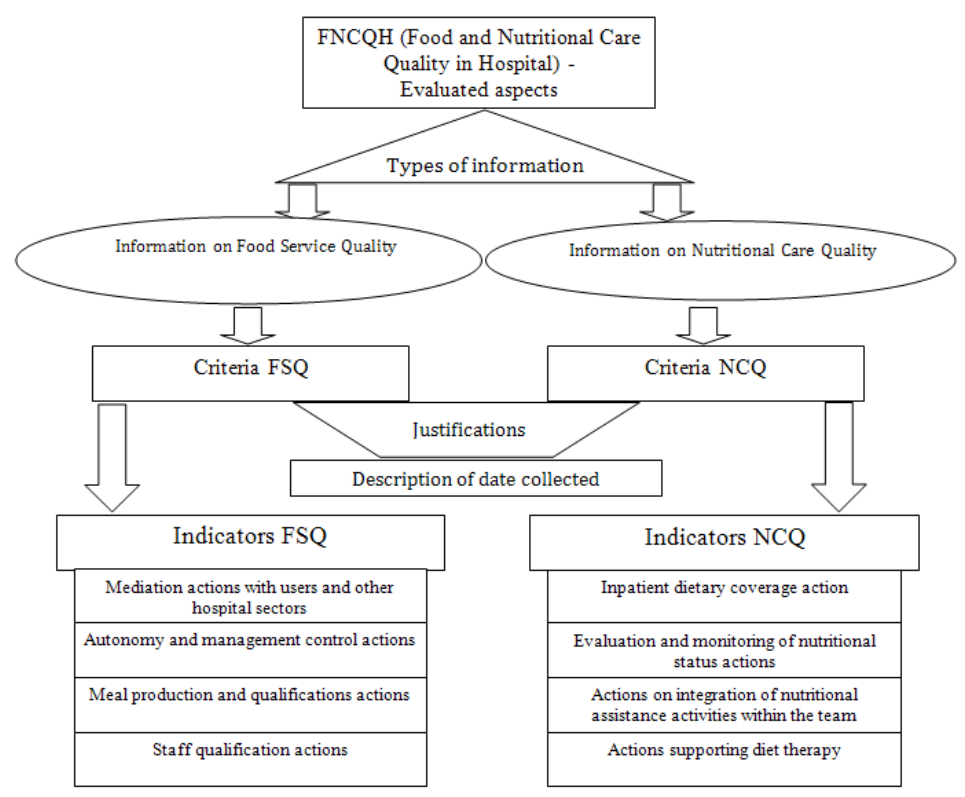

Figure 1. Flow diagram for the construction of indicators to assess the Food and Nutritional Care Quality in Hospital

\section{Results}

Tables 3 and 4 present the justifications and requirements regarding each criterion included in the NCQ and FSQ groups, respectively. Next, we organized the criteria shown in Tables 3 and 4 into indicators (NCQ and FSQ indicators) representing a group of related actions (Table 2). We constructed these indicators according to the aims of each group of actions to help identify which areas of the HFNS need more investment. The large amount of data derived from these indicators leads to more consistent results, thus facilitating evaluation of FNCQH quality.

The actions that characterize the NCQ indicators (Table 3) aim to detect and monitor the patient's nutritional status by means of integrated professional activities, so that (i) the entire team contributes to nutritional care, (ii) the nutrition service provides support to ensure that the nutritional practices offer technical information and dietary alternatives that meet patients' needs, and (iii) the patient has effective means of manifestation.

The nutritional care support actions characterizing the FSQ indicators (Table 4) depended on the meal production service. They consider the relationship between the service and users as well as the HFNS relation with other administrative organs within the institution. The FSQ indicators also take the autonomy of management and the technical and functional quality of the service into account.

The total score of the NCQ and FSQ indicators represent the sum of all the criteria corresponding to the four groups of actions mentioned in Tables 3 and 4, respectively. The sum of the criteria constituting each indicator ranged from 3 to 6 , which were transformed into a percent representation of $25 \%$. The total score of the NCQ and FSQ indicators was given as percentage. 
Table 2. Criteria constituting the Nutritional Care Quality (NCQ) and Food Service Quality (FSQ) corpora

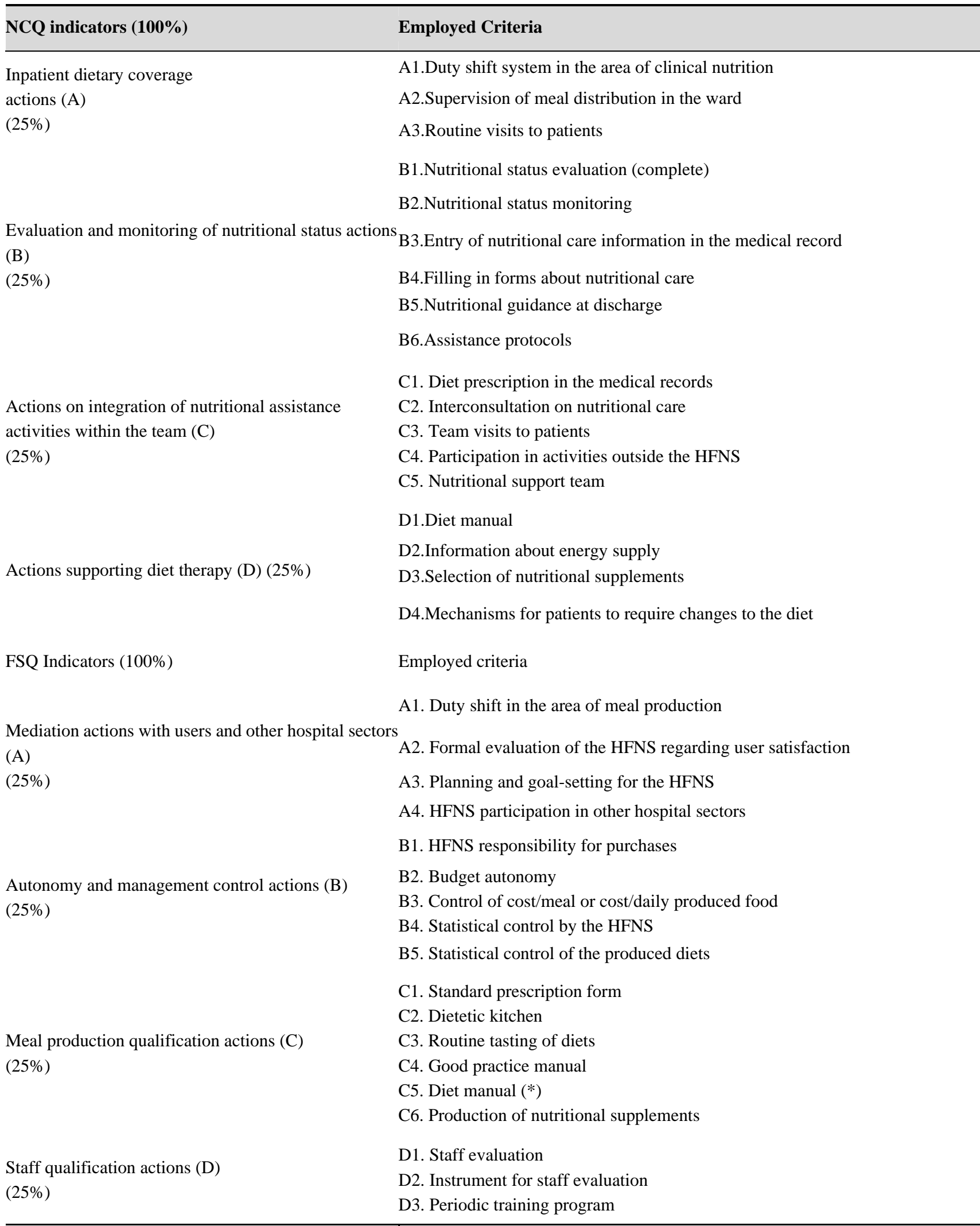

$(*)$ This criterion was considered important in both NCQ and FSQ. HFNS: Hospital Food and Nutrition Service 
Table 3. Criteria constituting the Nutritional Care Quality (NCQ) corpus

\begin{tabular}{|c|c|c|c|}
\hline & Criteria & Justifications & Description of date collected \\
\hline A1 & $\begin{array}{l}\text { Duty shift system in the area } \\
\text { of clinical nutrition }\end{array}$ & $\begin{array}{l}\text { Allows coverage of new admissions, discharges, emergencies, and } \\
\text { eventualities in the various specialties. Enables monitoring of nutritional } \\
\text { care and solution of nutritional problems. Mediates relation between meal } \\
\text { production and inpatient nutrition care. }\end{array}$ & $\begin{array}{l}\text { A dietitian is present during duty shifts; the dietician is also } \\
\text { responsible for providing assistance in the ward. The } \\
\text { information is based on the description of the duty shift } \\
\text { system. }\end{array}$ \\
\hline A2 & $\begin{array}{l}\text { Supervision of meal } \\
\text { distribution in the ward }\end{array}$ & $\begin{array}{l}\text { Evaluates the patient's food intake, diet distribution, and the suitability of the } \\
\text { diet and portions on the basis of the initial prescription. }\end{array}$ & $\begin{array}{l}\text { eDaily supervision of meal distribution in the ward is } \\
\text { accomplished by a dietitian }\end{array}$ \\
\hline A3 & Routine visits to patients & Enables monitoring and diagnosis of eventualities affecting dietary intake. & $\begin{array}{l}\text { Routine daily visits are done even when only patients with } \\
\text { specific characteristics regarding the type of disease, the } \\
\text { nutritional risk, the use of enteral or special diets are being } \\
\text { considered for supervision. (does not include coverage of all } \\
\text { beds). }\end{array}$ \\
\hline B1 & Nutritional status evaluation & $\begin{array}{l}\text { Allows diagnosis of the nutritional status. The use of anthropometric and } \\
\text { biochemical indicators as well as dietary history for nutritional evaluation } \\
\text { consolidates complete nutritional evaluation. The dietary and nutritional } \\
\text { history is important since it furnishes information about the determinants of } \\
\text { the patient's current nutritional status and aids the professional in planning } \\
\text { interventions and issuing guidelines at discharge. }\end{array}$ & $\begin{array}{l}\text { Use of at least one parameter from each group of indicators } \\
\text { (at least albumin, Body Mass Index - BMI, and dietary } \\
\text { history). }\end{array}$ \\
\hline
\end{tabular}

B2 Nutritional status monitoring Indicates how the progress of the nutritional status is being followed.

Nutritional evaluation is performed two or more times during hospitalization, even though fewer indicators are used in the second evaluation.

Entry of nutrition care

B3 information in the medica record

B4

Filling in forms about nutrition care

B5

Nutritional guidance at discharge

B6 care

Participation in activities outside the HFNS supply
Informs the team about the nutritional status, food consumption, nutritional Routine procedures are entered in the patient's medical requirements, and diet therapy strategies. records.

Indicates the organization of procedures for nutritional assistance. Ensures that information about nutrition care is entered in the medical records.

Indicates the need to continue the treatment. These guidelines should be an integral part of the activities on nutritional education directed toward hospitalized patients.

Indicates systematization of nutrition care, including criteria and parametersExistence of at least one assistance protocol, regardless of for nutritional assistance.

Ensures that the multi professional team is informed about the nutrition care delivered to the patient. Allows identification of the staff member responsible for nutritional assistance actions.

Interconsultation on nutrition Ensures nutrition care takes place in other non-covered areas. Facilitates access to nutrition care in the various wards. Demands continuous professional development. Implements actions of nutritional therapy for patients requiring special nutrition care.

Provides the team with a repertory of routine and special diets. Allows the production of diets that meet the nutritional requirements of the patient. Speeds up and optimizes the most suitable nutritional intervention.

Information about the energy Provides information about the energy supply of the diets, enabling the staff to adjust them to the patient's needs.

Informs about the production of preparations with specific nutritional purposes. Indicates concern for the patient's dietary intake.

Contributes to prevention of malnutrition during hospitalization.
Nutritional assistance printed form is attached to the medical records.

Nutritional guidance is given even when dietary orientation at discharge should be provided only to groups of patients with specific characteristics regarding the type of disease, the nutritional risk, the use of enteral or special diet. (does not include coverage of all beds). which procedures are included.

Situations requiring changes to the diet are entered in the medical records, without considering frequency or coverage.

Formal assistance activity with a written record of the request and the adopted procedure, thus establishing a common means of assistance for beds not covered by nutritional status evaluation. This is important when the number of dietitians is insufficient to cover all beds.

Routine visits with the team are conducted at least once a week. Occasional visits in special situations or visits taking place with a frequency of less than once a week are not considered

Activities are performed in collaboration with other services or with groups of patients. There are periodic lectures, journals, newsletters, discussion meetings, etc.

The nutritional support team is formalized and active.

There is a printed manual in the HFNS containing some kind of nutritional information.

fThere is at least information about the energy supply of routine hospital diets.

Industrialized supplements and local production of preparations for nutritional supplementation are available. Mechanisms for the patient to request modifications to the diet are available by directly addressing the professional involved in such procedure during routine visits. Requests for diet modification made to professionals other than physicians and dietitians were not taken into account, since they were not considered to be direct. 
Table 4. Criteria constituting the Food Service Quality (FSQ) corpus

\begin{tabular}{|c|c|c|c|}
\hline & Criteria & Justifications & Description of date collected \\
\hline A1 & $\begin{array}{l}\text { Duty shift in the area of meal } \\
\text { production }\end{array}$ & $\begin{array}{l}\text { Allows solution of specific problems and requirements on weekends and holidays, } \\
\text { ensuring that the process of meal production is covered during these days. }\end{array}$ & $\begin{array}{l}\text { Duty shift with the presence of a dietitian takes } \\
\text { place in the area of meal production of the } \\
\text { HFNS*. Information is based on the description } \\
\text { of the duty shift system. }\end{array}$ \\
\hline A2 & $\begin{array}{l}\text { Formal evaluation of the } \\
\text { HFNS regarding user } \\
\text { satisfaction }\end{array}$ & $\begin{array}{l}\text { Indicates concern about the quality of Hospital Nutrition Care delivered to users. } \\
\text { Provides a means of communication between the user and the HFNS. This } \\
\text { evaluation can also aid planning within the service (menus, etc.). }\end{array}$ & $\begin{array}{l}\text { Formal evaluation is performed by the HFNS* } \\
\text { (with a formal record). }\end{array}$ \\
\hline A3 & $\begin{array}{l}\text { Planning and goal-setting for } \\
\text { HFNS }\end{array}$ & $\begin{array}{l}\text { Implements actions for improvement of the quality of the produced diets and } \\
\text { nutritional assistance. Indicates systematization and control. Requires indicators, } \\
\text { evaluation, and systematized actions. }\end{array}$ & $\begin{array}{l}\text { Planning and goal setting is based on the HFNS } \\
\text { data, and is then documented and shared with } \\
\text { other administrative sectors. }\end{array}$ \\
\hline A4 & $\begin{array}{l}\text { HFNS participation in other } \\
\text { hospital sectors }\end{array}$ & $\begin{array}{l}\text { Indicates HFNS insertion and representative space. Increases the capacity of the } \\
\text { HFNS to participate in decisions. Informs other sectors about the HFNS actions. }\end{array}$ & $\begin{array}{l}\text { The HFNS participates in administrative sectors, } \\
\text { committees, periodic meetings, and } \\
\text { multidisciplinary teams, among others. }\end{array}$ \\
\hline B1 & $\begin{array}{l}\text { HFNS responsibility for } \\
\text { purchases }\end{array}$ & Allows the choice of quality products by the HFNS. & $\begin{array}{l}\text { Purchases are made by the HFNS, regardless of } \\
\text { the mechanism. }\end{array}$ \\
\hline B2 & Budget autonomy & $\begin{array}{l}\text { Enables flexible decision-making in terms of the financial planning of the service } \\
\text { and the establishment of priorities. The mechanism of direct purchase facilitates } \\
\text { product choice. }\end{array}$ & $\begin{array}{l}\text { The HFNS has autonomy to decide and make } \\
\text { purchases. }\end{array}$ \\
\hline B3 & $\begin{array}{l}\text { Control cost/meal or } \\
\text { cost/daily produced food }\end{array}$ & $\begin{array}{l}\text { Allows adequate use of the available financial resources, leading to improved } \\
\text { quality of the provided meals. Offers support to purchase planning. }\end{array}$ & The HFNS is responsible for cost control. \\
\hline B4 & $\begin{array}{l}\text { Statistical control by the } \\
\text { HFNS }\end{array}$ & $\begin{array}{l}\text { Indicates meal production control, HFNS organization, and capacity for evaluation. } \\
\text { Aids assessment of the prescribed diets. }\end{array}$ & $\begin{array}{l}\text { Statistical control of the production, } \\
\text { productivity, and assistance. }\end{array}$ \\
\hline $\mathrm{C} 1$ & Standard prescription form & $\begin{array}{l}\text { Allows standardization of the preparations in terms of nutritional and sensory } \\
\text { aspects. Ensures that the portions meet the patients' nutritional needs. Supports diet } \\
\text { therapy actions. }\end{array}$ & $\begin{array}{l}\text { The HFNS has a standard prescription form, } \\
\text { regardless of the number of covered } \\
\text { preparations. }\end{array}$ \\
\hline $\mathrm{C} 2$ & Dietetic kitchen & $\begin{array}{l}\text { Allows the production of diets and special preparations that meet the nutritional } \\
\text { specificities of the patients. Enables the design of new recipes with predefined } \\
\text { nutritional characteristics. The structure is directed at special dietary demands, thus } \\
\text { contributing to the quality of diet therapy. }\end{array}$ & $\begin{array}{l}\text { Specialized kitchen to cater for preparations and } \\
\text { diets with special nutritional characteristics. }\end{array}$ \\
\hline C3 & Routine tasting of diets & $\begin{array}{l}\text { Indicates concern about and monitoring of the sensory quality of the preparations } \\
\text { and diets provided by the service. }\end{array}$ & $\begin{array}{l}\text { Tasting performed by the dietitian, who is } \\
\text { responsible for the sensory quality of the diets. }\end{array}$ \\
\hline $\mathrm{C} 4$ & Good practice manual & $\begin{array}{l}\text { Guides the meal production actions, optimizing the production process. Consists in } \\
\text { a sanitary quality criterion. }\end{array}$ & $\begin{array}{l}\text { Good practice manual implemented in the } \\
\text { HFNS. }\end{array}$ \\
\hline C5 & Diet manual $(*)$ & $\begin{array}{l}\text { Standardizes meal production into diet categories. Allows for dietary and } \\
\text { nutritional planning, control of portions and preparations, and design of menus that } \\
\text { meet the patients' specific needs. Guides dietary prescription. Qualifies the } \\
\text { produced diets from a nutritional viewpoint. }\end{array}$ & $\begin{array}{l}\text { There is a printed HFNS manual containing } \\
\text { some nutritional information (at least the energy } \\
\text { content). }\end{array}$ \\
\hline C6 & $\begin{array}{l}\text { Production of nutritional } \\
\text { supplements }\end{array}$ & $\begin{array}{l}\text { Indicates concern about the production of preparations that meet the patients' } \\
\text { nutritional and dietary needs (in their sensory and symbolic aspects). Evaluates the } \\
\text { availability of meal production aimed at improving food intake by the patient. }\end{array}$ & $\begin{array}{l}\text { There is production of preparations such as } \\
\text { nutritional supplements. }\end{array}$ \\
\hline D1 & Staff evaluation & Reflects a human resources policy and commitment with staff quality. & $\begin{array}{l}\text { Periodic evaluation of the staff is performed by } \\
\text { the HFNS, regardless of the time interval. }\end{array}$ \\
\hline D2 & $\begin{array}{l}\text { Instrument for staff } \\
\text { evaluation }\end{array}$ & $\begin{array}{l}\text { Indicates systematization of the staff evaluation process. Reflects a human } \\
\text { resources policy. }\end{array}$ & $\begin{array}{l}\text { The existence of an instrument or other } \\
\text { systematic means of evaluation such as } \\
\text { meetings, printed forms, among others }\end{array}$ \\
\hline D3 & Periodic training program & $\begin{array}{l}\text { Updates procedures and information. Guarantees the quality of nutritional } \\
\text { assistance. Indicates investment in human resources. }\end{array}$ & $\begin{array}{l}\text { Staff training is accomplished with defined } \\
\text { program and periodicity, regardless of the time } \\
\text { interval. }\end{array}$ \\
\hline
\end{tabular}

* This criteria was considered important in both NCQ and FSQ; HFNS*: Hospital Food and Nutrition Service 


\section{Discussion}

Adequate FNCQH should involve aspects related to patient care as well as nutritional status evaluation and monitoring ${ }^{[9,25]}$. It should be associated with food and nutritional strategies that ensure a satisfactory dietary intake, and hence good patient evolution during the hospital stay ${ }^{[10,14]}$. FNCQH should also guarantee that meal production provides the patient with a suitable diet in terms of nutritional, sensory, and sanitary quality ${ }^{[12,26]}$.

We obtained the proposed FNCQH indicators on the basis of information acquired using the Instrument for Evaluation of Food and Nutrition Care ${ }^{[24]}$. We organized the information into two groups, and they allowed us to evaluate the quality of nutritional care delivered to the patient and of the structure available in the institution for FNCQH. We were able to detect the weaknesses of the HFNS, which should facilitate the design of measures that can improve the service. Repeated use of this instrument can also show whether the goals are reached, which is crucial to service quality ${ }^{[27]}$. Although we attempted to cover as much information about the FNCQH as possible, the measures proposed here may not be enough to map all the types of problems present in institutions, such as interrelations between the actions and their coverage.

The dietitian should participate in all the actions considered relevant for nutritional care. However, a study describing the roles of each professional within the multidisciplinary team reported that the dietitian's function was to help implement patient diets and nutritional evaluation and education, but there was no mention of the importance of this professional in the process of meal production ${ }^{[25]}$. The interdependence of meal production actions and patient care has not been extensively described. Establishing the necessary measures and designating the staff members responsible for them are two of the obstacles reported in various studies ${ }^{[11,28]}$. Although the present NCQ and FSQ indicators do not focus on this relation, it is possible to define the staff members responsible for the actions by identifying the points that need improving. Cooperation and communication among team members is beneficial to patients, since a more effective information exchange improves the quality of nutritional assistance ${ }^{[10]}$.

Lassen et al. ${ }^{[16]}$ evaluated three Danish hospitals and identified the problems related to inpatient nutritional care in these institutions. These authors proposed improvements to the FNCQH and estimated the costs involved in the implementation of these proposals. The authors suggested that (i) hospital administration should prioritize nutritional care and offer access to administrative tools in order to ensure quality nutrition; (ii) the nursing team working in the wards should allot time for patient diet support; (iii) contact between the hospital kitchen staff responsible for meal production and the nursing staff should be facilitated; (iiii) the multi professional team and the patient should communicate better regarding the choice of food and nutrition. Some of the criteria included in the QIPNC and QHMP indicators can contribute to the discussion about the relationship between the meal producing unit and patient care. Moreover, the indicators dealing with the mediation between services and the health team can furnish information about the situation.

According to the Brazilian Law No. 8234 of September 17, 1991 ${ }^{[29]}$, which regulates the activities of dietitians in Brazil, these professionals are responsible for prescribing, planning, analyzing, supervising, and evaluating the meal production process involved in inpatient and outpatient nutritional care. Despite the extent of these activities, their institutional systematization should be part of hospital nutritional assistance and they should be included in the indicators of hospital quality. If hospital managers realize the importance and impact of nutritional assistance on the patient's health status and satisfaction, these actions should directly contribute to the quality of hospital care.

The high rates of intra-hospital malnutrition observed in several recent studies ${ }^{[2,7,22]}$ may be related to failure of the current nutritional care system. This represents an independent risk factor regarding the rising number of complications, increased mortality, longer hospital stays, and higher costs ${ }^{[3,8]}$. Indicator of coverage and nutritional status monitoring of the present NCQ aims to prevent intra-hospital malnutrition. Since we did not evaluate coverage here, many of the proposed actions are directed at patients who require higher feeding needs or multi professional staff that are more concerned about the nutritional status of their patients. 
Re-assessing the established criteria is mandatory and these criteria must really reflect indicators of hospital quality ${ }^{[27]}$. Recognizing nutrition care as part of patient care, understanding the contribution of nutritional assistance to the quality of hospital service ${ }^{[24,26]}$, and using scores to measure this type of assistance shall contribute to constructing more solid indicators for the assessment of the institution by regulating organs.

To articulate a scope of inpatient and outpatient nutrition care that reflects the characteristics and objectives of the institution, it is necessary to revise the set of actions, in order to improve the quality and efficacy of the FNCQH ${ }^{[24]}$. New FNCQH demands require that the institution realizes the relationship between malnutrition and hospitalization costs and length. It is also necessary to consider the resources and priorities at this level of nutritional care.

In spite of the cultural differences expressed in the institutional structures, the proposed indicators contribute to characterize and compare hospital nutritional care. On the other hand, the indicators were designed so that actions can be included and modified. It is possible to make adjustments in accordance with the needs and the hospital context of different places.

\section{Conclusion}

Considering the NCQ and the FSQ, the FNCQH indicators can help assess the quality of the nutritional service and pinpoint the segments that deserve more investment and restructuring. The proposed indicators include many actions and allow for comparison between services, so it can serve as an instrument that evaluates and monitors the HFNS.

Recognizing the need for a set of actions that improve patient nutritional status shall aid institutions to incorporate nutritional care as a fundamental part of their routine. Thus, the health team should be involved in strategies that consider the objective and subjective needs of the patient. Additionally, support actions by the meal production service should be integrated with patient care and the institutional objectives. Finally, the meal production service and its staff should have the necessary technical qualifications and autonomy to implement improved diets.

\section{Acknowledgments}

This study was supported by FAPESP (Fundação de Amparo à Pesquisa do Estado de São Paulo), Brazil.

\section{References}

[1] Waitzberg DL, Caiaffa WT, Correia MI. Hospital malnutrition: the Brazilian national survey (IBRANUTRI): a study of 4000 patients. Nutrition. 2001; 17(7-8), 573-80. PMid: 11448575 http://dx.doi.org/10.1016/S0899-9007(01)00573-1

[2] Penie JB, Malnut CGSH. State of malnutrition in Cuban hospitals. Nutrition. 2005; 21(4): 487-97. PMid: 15811770 http://dx.doi.org/10.1016/j.nut.2004.08.019

[3] Leandro-Merhi VA, de Aquino JL, Sales Chagas JF. Nutrition status and risk factors associated with length of hospital stay for surgical patients. JPEN J Parenter Enteral Nutr. 2011; 35(2): 241-8 PMid: 20971940 http://dx.doi.org/10.1177/0148607110374477

[4] Leandro-Merhi VA, Diez Garcia RW, Monaco DV et al. Comparative analysis of nutritional status, food intake and length of hospitalization considering two hospitals: public versus private. Nutr Hosp. 2006; 21(1): 32-7. PMid: 16562810

[5] Sichieri R, do Nascimento S, Coutinho W. The burden of hospitalization due to overweight and obesity in Brazil. Cad Saude Publica. 2007; 23(7): 1721-7. http://dx.doi.org/10.1590/S0102-311X2007000700025

[6] Macinko J, Camargos V, Firmo JO et al. Predictors of 10-year hospital use in a community-dwelling population of Brazilian elderly: the Bambui Cohort Study of Aging. Cad Saúde Pública. 2011; 27 Suppl 3: S336-44. http://dx.doi.org/10.1590/S0102-311X2011001500003

[7] Norman K, Pichard C, Lochs H et al. Prognostic impact of disease-related malnutrition. Clin Nutr. 2008; 27(1): 5-15. PMid: 18061312 http://dx.doi.org/10.1016/j.clnu.2007.10.007

[8] Amaral TF, Matos LC, Tavares MM et al. The economic impact of disease-related malnutrition at hospital admission. Clin Nutr. 2007; 26(6): 778-84. PMid: 17936442 http://dx.doi.org/10.1016/j.clnu.2007.08.002 
[9] Caccialanza R, Klersy C, Cereda E et al. Nutritional parameters associated with prolonged hospital stay among ambulatory adult patients. CMAJ. 2010; 182(17): 1843-9. PMid: 20940233 http://dx.doi.org/10.1503/cmaj.091977

[10] Donini LM, Castellaneta E, De Guglielmi S et al. Improvement in the quality of the catering service of a rehabilitation hospital. Clin Nutr. 2008; 27(1): 105-14. PMid: 18063444 http://dx.doi.org/10.1016/j.clnu.2007.10.004

[11] Beck AM, Balknas UN, Camilo ME et al. Practices in relation to nutritional care and support-report from the Council of Europe. Clin Nutr. 2002; 21(4): 351-4. PMid: 12211176 http://dx.doi.org/10.1054/clnu.2002.0555

[12] Stanga Z, Zurfluh Y, Roselli M et al. Hospital food: a survey of patients' perceptions. Clin Nutr. 2003; 22(3): 241-6. http://dx.doi.org/10.1016/S0261-5614(02)00205-4

[13] Feldblum I, German L, Castel H et al. Individualized nutritional intervention during and after hospitalization: the nutrition intervention study clinical trial. J Am Geriatr Soc. 2011; 59(1): 10-7. PMid: 21087222 http://dx.doi.org/10.1111/j.1532-5415.2010.03174.x

[14] Dupertuis YM, Kossovsky MP, Kyle UG et al. Food intake in 1707 hospitalised patients: a prospective comprehensive hospital survey. Clin Nutr. 2003; 22(2): 115-123. PMid: 12706127 http://dx.doi.org/10.1054/clnu.2002.0623

[15] Mckee M, Healy J. Hospital in a Changing Europe (European Observatory on Health Care System). First ed. Buckingham Philadelphia: World Health Organization. 2002; 59-80.

[16] Lassen KO, Kruse F, Bjerrum M. Nutritional care of Danish medical inpatients--patients' perspectives. Scand J Caring Sci. 2005; 19(3): 259-67. PMid: 16101854 http://dx.doi.org/10.1111/j.1471-6712.2005.00337.x

[17] Kruizenga HM, Wierdsma NJ, Van Bokhorst MAE et al. Screening of nutritional status in The Netherlands. Clin Nutr. 2003; 22(2): 147-52. PMid: 12706131 http://dx.doi.org/10.1054/clnu.2002.0611

[18] Schindler K, Pernicka E, Laviano A et al. How nutritional risk is assessed and managed in European hospitals: a survey of 21,007 patients findings from the 2007-2008 cross-sectional nutritionDay survey. Clin Nutr. 2010; 29(5): 552-559. http://dx.doi.org/10.1016/j.clnu.2010.04.001

[19] Velasco C, Garcia E, Rodriguez V et al. Comparison of four nutritional screening tools to detect nutritional risk in hospitalized patients: a multicentre study. Eur J Clin Nutr. 2011; 65(2): 269-74. PMid: 21081958 http://dx.doi.org/10.1038/ejcn.2010.243

[20] Planas M, Audivert S, Perez-Portabella C et al. Nutritional status among adult patients admitted to a university-affiliated hospital in Spain at the time of genoma. Clin Nutr. 2004; 23(5): 1016-24. PMid: 15380891 http://dx.doi.org/10.1016/j.clnu.2004.01.003

[21] Diez-Garcia RW. Hospital diet from the perspective of those involved in its production and planning. Rev Nutr. 2006; 19(2): 129-44 http://dx.doi.org/10.1590/S1415-52732006000200001.

[22] Chima CS, Barco K, Dewitt ML et al. Relationship of nutritional status to length of stay, hospital costs, and discharge status of patients hospitalized in the medicine service. J Am Diet Assoc. 1997; 97(9): 975-8, quiz 979-80. http://dx.doi.org/10.1016/S0002-8223(97)00235-6.

[23] Diez-Garcia RW, Sousa AA, Proença RPC. Qualifying instrument for evaluation of food and nutritional care in hospital. Nutr Hosp. 2012; 27(4): 1154-1161. PMid: 23165559 http://dx.doi.org/10.3305/nh.2012.27.4.5868

[24] Diez-Garcia RW, Sousa, AA, Proença, RPC, Leandro-Merhi, VA, Martinez, EZ. Gauging food and nutritional care quality in hospitals. Nutrition Journal. 2012; 11: 66. PMid: 22954229 http://dx.doi.org/10.1186/1475-2891-11-66

[25] Saar SRC, Trevizan MA. Los roles profesionales de un equipo de salud: la visión de sus integrantes. Rev Latino-Am Enfermagem. 2007; 15(1): 106-12. http://dx.doi.org/10.1590/S0104-11692007000100016.

[26] Diez-Garcia RW, Padilha M, Sanches M. Hospital food: proposals for qualification of the Food and Nutrition Service, evaluated by the scientific community. Cien Saúde Colet. 2012; 17(2): 473-480. PMid: 22267041 http://dx.doi.org/10.1590/S1413-81232012000200020

[27] Ovretveit J, Gustafson D. Improving the quality of health care - Using research to inform quality programmes. Brit Med J. 2003; 326 (7392): 759-61. http://dx.doi.org/10.1136/qshc.2003.009761

[28] Lindorff-Larsen K, Hojgaard Rasmussen H, Kondrup J et al. Management and perception of hospital undernutrition-a positive change among Danish doctors and nurses. Clin Nutr. 2007; 26 (3): 371-8.

PMid: 17383776 http://dx.doi.org/10.1016/j.clnu.2007.01.006

[29] Conselho Federal de Nutricionistas. Regulamenta a profissão de nutricionista e determina outras providências. Lei N 8.234, 17 de setembro de 1991 (DOU 18/09/1991). 